\title{
KEEFEKTIFAN BIMBINGAN KELOMPOK COGNITIVE BEHAVIOR DALAM MEREDUKSI POLA PIKIR NEGATIF SISWA SMK
}

\author{
Rama Cahyadi \\ e-mail: ramacahyadi.bk@gmail.com \\ SMK Kepuhdoko Tembelang Jombang
}

Jl. H. Sulaiman No. 95 Kepuhdoko, Tembelang, Jombang, Jawa Timur

\begin{abstract}
Abstrak: Penelitian ini bertujuan untuk menguji keefektifan bimbingan kelompok cognitive behavior dalam mereduksi pola pikir negatif siswa SMK. Penelitian dilaksanakan mulai dari bulan Februari sampai dengan Juli 2018, yang bertempat di SMK Kepuhdoko Tembelang Jombang. Penelitian ini menggunakan rancangan eksperimen dengan desain One Grup Pretest and Posttest Design. Data dianalisis dengan uji $t$-test Paired Sample Test, diperoleh hasil $t_{\text {hitung }}$ adalah 6.500 dan angka probabilitas (Sig. (2-tailed) adalah 0.001 dengan $\mathrm{df}=5$. Selanjutnya hasil tersebut dibandingkan dengan $\mathrm{t}_{\text {tabel }}$ pada taraf signifikan $5 \%$ uji 2 pihak dengan $\mathrm{df}=5$, sehingga diketahui $\mathrm{t}_{\text {tabel }}$ adalah 2.571 atau $6.500>2.571$. Nilai probabilitas yang diperoleh adalah $0.001>0,005$ maka dapat disimpulkan bimbingan kelompok cognitive behavior efektif mereduksi pola pikir negatif siswa SMK. Berdasarkan hasil penelitian disarankan bagi guru Bimbingan dan Konseling untuk menerapkan bimbingan kelompok cognitive behavior sebagai salah satu alternatif bantuan dalam mereduksi pola pikir negatif siswa SMA. Bagi peneliti selanjutnya dapat menggunakan hasil penelitian ini untuk dijadikan rujukan yang berhubungan dengan bimbingan kelompok cognitive behavior, dan peneliti selanjutnya bisa menggunakan desain penelitian lain selain one group pretest and posttest design, misalnya desain time series dan single subject design.
\end{abstract}

Kata-kata kunci: bimbingan kelompok cognitive behavior, pola pikir negatif, siswa SMK

\section{THE EFFECTIVENESS OF COGNITIVE BEHAVIOR GROUP GUIDANCE IN REDUCING NEGATIVE MINDSET OF VOCATIONAL SCHOOL STUDENTS}

\begin{abstract}
This study aims to examine the effectiveness of cognitive behavior group guidance in reducing the negative mindset of vocational students. The study was carried out starting from February to July 2018, which took place at the SMK Kepuhdoko Tembelang Jombang. This study used an experimental design with the design of the Pretest and Posttest Design Group. Data were analyzed by Paired Sample Test $t$-test, obtained the result of $t_{\text {count }}$ was 6,500 and probability number (Sig. (2-tailed) was 0.001 with $d f=5$. Then the results were compared with the $t_{\text {table }}$ at a significant level of $5 \%$ test 2 parties with $d f=5$, so that the $t_{\text {table }}$ is 2.571 or $6,500>2,571$. The probability value obtained is $0.001>0.005$, so it can be concluded that cognitive behavior group guidance is effective in reducing the negative mindset of vocational high-school students based on the results of the research recommended for teacher's guidance and counseling. Applying cognitive-behavioral group guidance as one of the alternative help in reducing the negative mindset of high-school students. Furthermore, researchers can use the results of this study to be used as a reference related to cognitive behavior group guidance, and further researchers can use research designs other than one group pretest and posttest design, for example time series design and $n$ single-subject design.
\end{abstract}

Keywords: cognitive behavior group guidance, negative mindset, vocational high-school students

\section{PENDAHULUAN}

Pendidikan kejuruan adalah pendidikan yang mempersiapkan peserta didik untuk dapat bekerja dalam bidang tertentu. Pengertian ini mengandung pesan bahwa setiap institusi yang menyelenggarakan pendidikan kejuruan harus berkomitmen menjadikan tamatannya mampu bekerja dalam bidang tertentu (Depdiknas, 2012).

Menurut Habsy (2017a), pada saat individu memasuki tahapan pendidikan di sekolah menengah, maka individu memasuki masa remaja. Pada masa ini, remaja mulai mempunyai kapasitas untuk memperoleh dan menggunakan pengetahuan secara efisien 
mencapai puncaknya dikarenakan pertumbuhan otak mencapai kesempurnaan. Sistem saraf yang berfungsi memproses informasi berkembang dengan cepat. Di samping itu, pada masa remaja ini juga terjadi reorganisasi lingkaran saraf frontal lobe (belahan otak bagian depan sampai pada belahan atau celah sentral). Frontal lobe ini berfungsi dalam aktivitas kognitif tingkat tinggi, seperti kemampuan merumuskan perencanaan strategi atau kemampuan mengambil keputusan (Sarwono dalam Sary, 2017).

Proses kognitif memainkan peran sangat penting dalam mengatur kecemasan dan kebahagiaan pada seseorang (Butler \& Mathews dalam Rusydi, 2012). Selain itu, proses berpikir sangatlah penting karena berhubungan dengan perilaku dan berbagai keberhasilan hidup seseorang (Lyubomirsky, dkk dalam Rusydi, 2012).

Erikson (dalam Hurlock, 1966) mengungkapkan bahwa perkembangan remaja sedang berada dalam tahap kelima dari seluruh perkembangan manusia. Tugas perkembangan remaja menurut Erikson adalah untuk menemukan siapa dirinya, apa perannya dalam masyarakat, dan kemana arah perjalanan hidupnya (Santrock, 2003). Berkaitan dengan upaya pencapaian tugas perkembangan ini, remaja memerlukan bimbingan, pengetahuan, dan keterampilan agar pikiran-pikiran negatif dapat diubah menjadi pikiranpikiran yang positif.

Menurut Adelia (dalam Mardhika, 2016) pola pikir negatif adalah pola atau cara berpikir yang lebih condong pada sisi-sisi negatif dibanding sisi-sisi positifnya. Hal ini dapat dilihat dari kepercayaan diri atau pandangan yang terucap, sikap individu, dan perilaku. Sementara itu, Rasyid (dalam Mardhika, 2016) mengartikan pikiran negatif sebagai sekumpulan pikiran salah yang menghambat langkah manusia menuju kondisi yang lebih baik dan membuat perilaku manusia tidak terarah. Pemikiran yang tidak baik akan berdampak pada individu, yakni menjadi individu yang lemah dan tidak bisa mengerjakan pekerjaan maksimal karena dirinya mempunyai anggapan tidak dapat berhasil dan sukses. Pola pikir negatif menurut Williams (dalam Mardhika, 2016) yaitu kecendurungan individu untuk memandang segala sesuatu dari sisi negatif. Manusia dengan pemikiran negatif akan selalu terus memberikan penilaian pada dirinya tidak mampu dan selalu mengkhawatirkan kejadian yang belum terjadi, pemikiran ini akan memberikan pengaruh pada kehidupan individu tersebut.

Menurut Adelia (dalam Mardhika, 2016) pikiran negatif disebabkan oleh konstruksi persepsi seseorang berdasarkan atas sistem keyakinan, cara pandang, atau cara seseorang menelaah suatu permasalahan. Menurut Adelia (dalam Wati, 2017), berpikir negatif memberikan pengaruh buruk yang lebih besar dari dampak positifnya, berpikir negatif juga menyebabkan seseorang tertekan dan kehilangan banyak energi, dampak yang lebih buruk dari berpikir negatif yaitu mengakibatkan manusia tidak mampu lagi berbuat sesuatu untuk menciptakan prestasi. Menurut Syafi'ie (dalam Mardhika, 2016) dengan berpikir positif, secara otomatis akan memengaruhi jiwa manusia menjadi lebih optimis, imajinasi menjadi lebih kreatif, dan semangat menjadi semakin kuat.

Pola pikiran negatif dapat mempengaruhi aspek kognitif, afektif, behavioral, motivasional, dan somatik (Dewi, Tobing, \& Hizkia, 2014). Dampak pada aspek kognitif yaitu menyebabkan sulit berkonsentrasi, sulit membuat keputusan, muncul ide irasional, dan logical error, sedangkan dampak pada aspek behavioral seperti aktivitas yang menurun dan menarik diri. Dampak pada aspek afektif seperti cemas, sedih, merasa bersalah, marah, malu, stres, dan depresi. Dampak pada aspek motivasional seperti hilang minat dan menunda, serta dampak pada aspek somatik seperti sulit tidur (insomnia) dan nafsu makan berkurang.

Perkembangan penilaian kognitif individu tergantung dari aspek persepsi, perhatian, pemilahan, dan generalisasi atas interaksinya dengan lingkungan. Penilaian kognitif dibentuk secara aktif oleh proses mental individu ketika berinteraksi dengan lingkungannya yang ditransformasi ke dalam pikiran berdasarkan struktur kognitif yang telah ada. Piaget menegaskan bahwa penilaian kognitif dibangun dalam pikiran individu. Suatu realita atau pengalaman tidak terletak dalam realita itu sendiri, tetapi manusialah yang membangun penilaiannya terhadap realita yang menjadi suatu makna tertentu (Habsy, 2018a). Oleh karena itu, individu perlu menyadari pikirannya dan memperhatikan bagaimana pikiran dapat mempengaruhi tindakan.

Williams (dalam Mardhika, 2016) mengatakan bahwa secara garis besar, terbentuknya pola pikir (thought style) manusia dipengaruhi oleh tiga faktor utama yaitu (1) kultur, (2) kedudukan sosial, dan (3) kecenderungan personal. Menurut Rini (2002) ciri-ciri individu yang mempunyai pola pikir negatif sebagai berikut (1) dalam menyikapi kegagalan atau ketidak berhasilan menganggap nasibnya jelek dan cenderung putus asa, (2) cenderung menganggap orang lain itu negatif, dan (3) tidak yakin dengan peluang usahanya. Pola pikir negatif tentunya akan memberikan dampak negatif bagi kesehatan fisik, seperti yang dikemukakan 
oleh Elfiky (2013) bahwa berpikiran negatif dapat memberikan dampak bagi kesehatan fisik, diantaranya (1) hipertensi, (2) gangguan pencernaan, dan (3) kenaikan pada berat badan. Pola pikir negatif tersebut dipengaruhi karena adanya faktor-faktor berikut (1) riwayat masa lalu, (2) keinginan yang lemah atau bahkan tidak memiliki tujuan yang jelas, (3) rutinitas negatif, (4) pengaruh internal, dan (5) pengaruh eksternal (Elfiky, 2013).

Pola pikir negatif dalam penelitian ini adalah cara berpikir yang lebih mengarah pada sisi-sisi negatif dibanding sisi-sisi positifnya. Hal ini dapat dilihat dari kepercayaan diri atau pandangan yang terucap, sikap individu, dan perilaku. Pikiran negatif disebabkan oleh konstruksi persepsi seseorang berdasarkan atas sistem keyakinan, cara pandang, atau cara seseorang menelaah suatu permasalahan. Pemikiran yang tidak baik akan berdampak pada individu menjadi individu yang lemah dan tidak bisa mengerjakan pekerjaan maksimal karena dirinya mempunyai anggapan tidak dapat berhasil dan sukses. Dalam penelitian ini, pola pikir diukur dengan kuesioner berdasarkan teori Elfiky (2013) yang menyatakan faktor penyebab pola pikir negatif, yaitu (a) riwayat masa lalu; (b) keinginan yang lemah atau bahkan tidak memiliki tujuan yang jelas; (c) rutinitas negatif; (d) pengaruh internal; dan (e) pengaruh eksternal.

Salah satu strategi layanan yang dapat diterapkan dalam mengatasi masalah ini adalah dengan bimbingan kelompok. Menurut Kartadinata (dalam Habsy, 2017b), bimbingan merupakan proses bantuan kepada individu untuk perkembangan optimum individu untuk memilih dan mengambil keputusan atas tanggungjawab sendiri, perkembangan optimum adalah perkembangan yang sesuai dengan potensi dan sistem nilai yang dianut.

Dalam proses bimbingan terdapat banyak macam pendekatan yang dapat digunakan untuk membantu siswa, tetapi dalam penelitian ini, pendekatan yang digunakan adalah cognitive behavior. Cognitive behavior merupakan psikoterapi yang berfokus pada kognisi yang dimodifikasi secara langsung, yaitu ketika individu mengubah pikiran maladaptifnya (maladaptive thought) maka secara tidak langsung juga mengubah tingkah lakunya yang tampak (overt action) (Spiegler \& Guevremont dalam Siregar, 2013).

Salah satu tujuan utama cognitive behavior menurut Beck (dalam Siregar, 2013) adalah untuk membantu individu dalam mengubah pemikiran atau kognisi yang irasional menjadi pemikiran yang lebih rasional. Menurut Satiadarma (dalam Muqodas,
2011) mengatakan bahwa penyimpangan perilaku manusia terjadi karena adanya penyimpangan fungsi kognitif. Untuk memperbaiki perilaku manusia yang mengalami penyimpangan tersebut terlebih dahulu harus dilakukan perbaikan terhadap fungsi kognitif manusia. Pernyataan ini menunjukkan pentingnya pengaruh aspek kognitif terhadap perilaku manusia. Peran kognitif dalam mempertimbangkan keputusan untuk melakukan tindakan tertentu menjadi fokus perhatian dalam pendekatan cognitive behavior.

Pendekatan cognitive behavior merupakan sebuah pendekatan yang memiliki pengaruh dari pendekatan cognitive therapy dan behavior therapy. Oleh sebab itu, cognitive behavior merupakan perpaduan pendekatan dalam psikoterapi yaitu cognitive therapy dan behavior therapy (Matson \& Ollendick dalam Muqodas, 2011) sehingga langkah-langkah yang dilakukan oleh cognitive therapy dan behavior therapy ada dalam konseling yang dilakukan oleh cognitive behavior therapy. Karakteristik cognitive behavior therapy yang tidak hanya menekankan pada perubahan pemahaman konseli dari sisi kognitif namun memberikan konseling pada perilaku ke arah yang lebih baik dianggap sebagai pendekatan yang tepat untuk diterapkan di Indonesia.

Tujuan utama pendekatan cognitive behavior, yaitu memunculkan respon yang lebih adaptif terhadap suatu situasi dengan menyesuaikan proses kognitif yang ada dan melakukan modifikasi perilaku (Westbrook, Kennerly, \& Kirk dalam Habsy, 2017a). Hal senada dikemukakan oleh Beck (dalam Habsy, 2017a) bahwa pendekatan cognitive behavior berusaha untuk mengidentifikasi dan mengoreksi keyakinankeyakinan yang disfungsional atau terdistorsi, tugas konselor cognitive behavior membantu konseli mengenali cacat-cacat logis, dalam pemikiran individu dan membantu untuk memandang situasi secara rasional. Konseli diminta untuk mengumpulkan buktibukti untuk menguji keyakinan, yang akan membawa konseli untuk mengubah keyakinan yang ternyata tidak berdasar realita.

Beck (dalam Habsy, 2017a) menyatakan cognitive behavior dalam bentuk kelompok sangat sesuai diterapkan bagi siswa, karena merupakan proses edukasi yang bertujuan mengajarkan konseli untuk menjadi terapis bagi dirinya sendiri, dan menekankan pada pencegahan. Beberapa teknik dalam pendekatan cognitive behavior antara lain modeling, behavior rehearsal, coaching, homework, feedback, reinforcment, cognitive restructuring, problem solving, the buddy system (Corey dalam Habsy, 2017a).

Berdasarkan kajian teori tersebut dapat 
disimpulkan bahwa bimbingan kelompok cognitive behavior merupakan proses pemberian informasi dan bantuan pada sekelompok orang dengan memanfaatkan dinamika kelompok guna mencapai suatu tujuan tertentu, yaitu merubah pola pikirnya. Bimbingan kelompok cognitive behavior lebih menekankan pada aspek kognisi untuk membantu individu mengenali kesalahan dalam berpikir dan membantu mereka untuk memandang situasi secara rasional. Pelaksanaan bimbingan kelompok cognitive behavior terdiri dari delapan tahapan, yaitu (1) memberikan pertanyaan langsung untuk menemukan pikiran negatif dan menyadarkan adanya perangkap negatif, (2) kontruksi pikiran otomatis, (3) relaksasi (4) mengidentifikasi masalah yang dihadapi, (5) keterampilan memecahkan masalah, (6) menetapkan tujuan, (7) latihan kognitif dengan menggunakan imajinasi untuk membayangkan secara detail mengenai tahap-tahap yang akan dilakukan oleh subjek dan konsekuensi yang mungkin dihadapi oleh subjek, serta (8) latihan untuk mengubah perilaku terhadap objek.

Berdasarkan latar belakang yang telah di uraikan, rumusan masalah dalam penelitian ini adalah apakah bimbingan kelompok cognitive behavior efektif mereduksi pola pikir negatif siswa SMK?

\section{METODE PENELITIAN}

\section{Desain Penelitian}

Penelitian yang dilakukan oleh peneliti adalah penelitian kuantitatif dengan jenis eksperimen. Penelitian ini menggunakan desain penelitian pra experiment design dengan menggunakan One Grup Pretest and Posttest Design. Lebih jelasnya desain penelitian ini dapat dilihat pada gambar 1 .

\begin{tabular}{llll} 
K & 01 & $X$ & 02 \\
\hline
\end{tabular}

Gambar 1. Rancangan penelitian

Keterangan:

$\mathrm{K}$ : subjek

$\mathrm{O} 1$ : pretest sebelum treatment

$\mathrm{X}$ : treatment

$\mathrm{O} 2 \quad$ : posttest setelah treatment

Untuk memperjelas eksperimen, dalam penelitian ini, disajikan langkah-langkah sebagai berikut (1) melakukan pretest, adalah pengukuran awal dengan menggunakan inventori pikiran negatif siswa kepada sampel penelitian sebelum diberikan perlakuan yaitu bimbingan kelompok cognitive behavior untuk mengetahui menurunnya pikiran negatif siswa, (2) melaksanakan layanan bimbingan kelompok pada responden, (3) menyebar inventori tentang pikiran negatif kepada siswa atau responden setelah diberikan eksperimen atau treatment sebagai posttest, dan (4) hasil data yang diperoleh dianalisis dalam rangka mengetahui keefektifan bimbingan kelompok cognitive behavior dalam mereduksi pola pikir negatif siswa.

Secara visual, kerangka kerja penelitian model bimbingan kelompok cognitive behavior untuk mereduksi pola pikir negatif diilustrasikan pada gambar 2 .

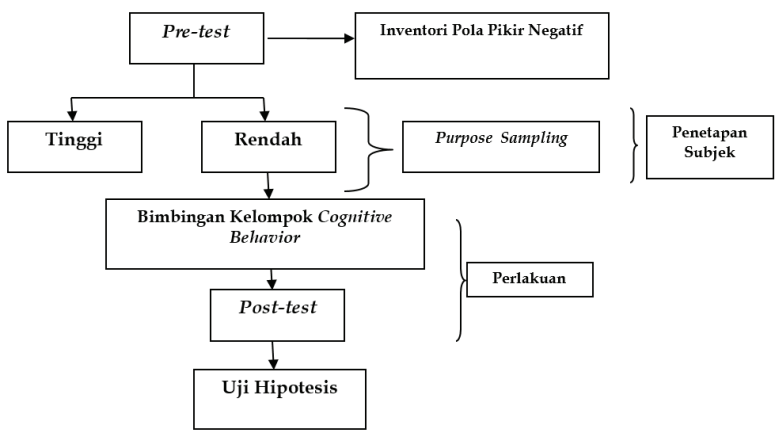

Gambar 2. Kerangka kerja penelitian (Sumber: Habsy, 2018b)

\section{Waktu Penelitian}

Prosedur intervensi yang diberikan kepada kelompok eksperimen menggunakan bimbingan kelompok cognitive behavior. Proses konseling dilaksanakan pada enam kali pertemuan yang masingmasing pertemuan berlangsung sekitar 40 menit. Waktu penelitian ini, disajikan pada tabel 1.

Tabel 1

Waktu Penelitian

\begin{tabular}{cll}
\hline No & \multicolumn{1}{c}{ Proses } & \multicolumn{1}{c}{ Waktu } \\
\hline 1 & Assesment dan diagnosa & 14 Februari 2018 \\
2 & Pendekatan kognitif & 21 Februari 2018 \\
3 & Formulasi status & 28 Februari 2018 \\
4 & Fokus terapi & 15 Maret 2018 \\
5 & Intervensi tingkah laku & 22 Maret 2018 \\
6 & Perubahan core beliefs & 29 Maret 2019 \\
7 & Pencegahan & 11 April 2019 \\
\hline
\end{tabular}

\section{Prosedur Pengumpulan Data}

Pengumpulan data dilakukan dengan menggunakan instrumen penelitian data berupa kuesioner pola pikir negatif. Adapun dalam menyusun instrumen pengumpulan data ini dengan mengambil konsep teori Elfiky (2013), yang menyatakan faktor 
penyebab pola pikir negatif terdiri dari (1) riwayat masa lalu, (2) keinginan yang lemah atau bahkan tidak memiliki tujuan yang jelas, (3) rutinitas negatif, (4) pengaruh internal, dan (5) pengaruh eksternal.

Untuk menguji tingkat validitas instrumen, peneliti mengujicobakan instrumen tersebut pada responden yang setara. Pengujian validitas menggunakan teknik uji validitas dengan rumus Korelasi Product Moment sebagai berikut.

$$
r_{x y}=\frac{N \sum x y-\left(\sum x\right)\left(\sum y\right)}{\sqrt{\left\{\mathrm{N} \sum x^{2}-\left(\sum \mathrm{x}\right)^{2}\right\} \cdot\left\{\mathrm{N} \sum y^{2}-\left(\sum \mathrm{Y}\right)^{2}\right\}}}
$$

Keterangan :

$r_{x y}=$ koefisien korelasi antara variabel $\mathrm{x}$ dan variabel $\mathrm{y}$

$\mathrm{n}=$ jumlah responden

$\Sigma \mathrm{x}=$ jumlah skor $\mathrm{x}$

$\Sigma y=$ jumlah skor $y$ (Arikunto, 2010)

Setelah hasil $r_{x y}$ diperoleh, kemudian dikonsultasikan dengan $r_{\text {tabel }}$ dengan taraf signifikan $a=5 \%$. Jika $r_{x y}$ lebih besar dari $r_{\text {tabel }^{\prime}}$ maka item butir angket tersebut tidak valid. Dari uji validitas yang telah dihitung oleh peneliti dengan rumus tersebut menggunakan alat bantu SPSS 16.00, maka dapat diketahui dari 82 butir soal ternyata ada 44 butir soal yang tidak valid, yaitu butir soal nomor 3, 4, 6, 8, 9, $10,14,15,16,17,18,19,20,21,22,23,25,26,28,29,33$, $34,35,36,37,38,41,43,49,50,51,55,57,58,60,62$, $63,64,65,68,69,70,71,79$, sedangkan butir soal yang valid sebanyak 38 butir, yaitu butir soal nomor 1, 2, 5, $7,11,12,13,24,27,30,31,32,39,40,42,44,45,46,47$, $48,52,53,54,56,59,61,66,67,72,73,74,75,76,77,78$, $80,81,82$. Butir-butir soal yang valid inilah yang akan digunakan sebagai alat ukur pada pretest dan posttest dalam penelitian ini.

Untuk menghitung reliabilitas instrumen digunakan rumus Alpha. Rumus Alpha digunakan untuk mencari reliabilitas instrumen yang skornya bukan 0 dan 1, misalnya inventori atau soal bentuk uraian (Arikunto, 2010). Rumus Alpha yang dimaksud adalah sebagai berikut.

$$
r_{i}=\left(\frac{k}{(k-1)}\right)\left(1-\frac{\sum \sigma_{b}^{2}}{\sigma_{t}^{2}}\right)
$$

Keterangan:

$\begin{array}{ll}\mathrm{r}_{\mathrm{i}} & \text { : koefisien reliabilitas yang dicari } \\ \mathrm{K} & \text { : banyaknya butir pertanyaan atau soal } \\ \sum \sigma_{b}^{2} & : \text { Jumlah variansi skor butir soal ke-i } \\ \mathrm{i} & : 1,2,3,4, \ldots . . \mathrm{n} \\ \sigma_{t}^{2} & \text { : variansi nilai (Arikunto, 2010) }\end{array}$

Kriteria pengujian reliabilitas adalah jika angka reliabilitas yang diperoleh lebih dari 0,60 ( $a>0,60)$ maka instrumen dikatakan reliabilitasnya tinggi, dan penghitungannya menggunakan program SPSS 16 for Windows. Hasil perhitungan reliabilitas instrumen dapat dilihat pada tabel 2.

Tabel 2

Hasil Uji Reliabilitas Angket Pola Pikir Reliability Statistics

\begin{tabular}{cc}
\hline Cronbach's Alpha & N of item \\
\hline .731 & 82 \\
\hline
\end{tabular}

Dari perhitungan variabel Y (pola pikir negatif) adalah 0,731 lebih besar dari 0,60(0,731 > 0,60), sehingga disimpulkan bahwa instrumen variabel Y (pola pikir negatif) tersebut reliabel, dan dapat digunakan untuk menjaring data yang diperlukan dalam penelitian ini. Langkah-langkah yang ditempuh dalam pengumpulan data kuesioner sebagai berikut.

\section{Penyusunan inventori penelitian}

Alat ukur yang digunakan untuk mengukur pola pikir negatif siswa adalah inventori pola pikir negatif, yang dirancang sendiri oleh peneliti berdasarkan pada komponen-komponen pola pikir negatif. Skala yang digunakan dalam penelitian ini adalah skala likert. Bentuk skala likert adalah bentuk pernyataan yang tertutup, yaitu sudah ditentukan alternatif jawaban sehingga responden memilih sesuai keadaan dirinya. Dalam skala likert mempunyai skala skor dari 1-4, dimana pada butir favorable dimulai dari 4-1, sedangkan untuk butir unfavorable dari 1-5.

\section{Kisi-kisi inventori pola pikir}

Adapun kisi-kisi inventori pola pikir yang dikembangkan berdasarkan teori Elfiky yaitu (a) riwayat masa lalu, (b) keinginan yang lemah atau bahkan tidak memiliki tujuan yang jelas, (c) rutinitas negatif, (d) pengaruh internal, dan (e) pengaruh eksternal.

\section{Penskoran inventori pola pikir}

Skala yang digunakan dalam penelitian ini mempunyai 4 alternatif jawaban dan responden bebas memilih salah satu jawaban dari keempat alternatif jawaban yang ada sesuai dengan keadaan masingmasing responden. Jawaban positif diberi skor 4,3,2,1 sedangkan jawaban soal negatif diberi skor 1,2,3,4 sesuai dengan pertanyaan yang dimaksud. Untuk lebih jelasnya penskoran inventori pola pikir dapat dilihat pada tabel 3 . 
Tabel 3

Pilihan Jawaban dan Skor

\begin{tabular}{lll}
\hline Pilihan Jawaban & \multicolumn{2}{c}{ Skor Item } \\
\cline { 2 - 3 } & + & - \\
\hline Sangat sering & 4 & 1 \\
Sering & 3 & 2 \\
Kadang-kadang & 2 & 3 \\
Tidak pernah & 1 & 4 \\
\hline
\end{tabular}

Untuk mengetahui perolehan skor bagi setiap responden yaitu dengan cara menjumlahkan skor jawaban item. Skor keseluruhan merupakan skor pola pikir negatif siswa. Untuk mengetahui pola pikir negatif siswa, digunakan tiga kategori yaitu skor tinggi, sedang, dan rendah. Menurut Hadi (dalam Sugiyono, 2013) penentuan ini dilakukan dengan cara berikut.

Kategori tinggi : (Mean skor + 1SD) ke atas

Kategori sedang : (Mean - 1SD) sampai (Mean + 1SD) Kategori rendah : (Mean - 1SD) ke bawah

Cara untuk mengetahui kategori di atas adalah dengan menggunakan program SPSS versi 16.00 for Windows. Sebelum inventori digunakan pada pretest untuk mengukur tingkat pola pikir siswa, sebelum perlakuan, inventori perlu diuji coba. Setelah dilakukan uji coba akan didapat atau diketahui inventori dapat digunakan untuk mengukur tingkat pola pikir siswa.

\section{Analisis Data}

Analisis data pada penelitian ini menggunakan T-test. Adapun rumus yang digunakan sebagai berikut.

$$
t=\frac{(M d)}{\sqrt{\frac{\sum x^{2} \mathrm{~d}}{N(N-1)}}}
$$

Keterangan rumus :

$\mathrm{Md} \quad=$ mean beda dari pretest-posttest

$\mathrm{X}^{2} \quad$ = jumlah kuadrat dari pasangan

$\mathrm{N} \quad=$ jumlah subjek (Arikunto, 2010)

Uji T-test ini digunakan untuk mengetahui efektif tidaknya pelaksanaan bimbingan kelompok terhadap siswa, dalam upaya mereduksi pola pikir negatif. Analisa data membandingkan data hasil pretest dengan hasil posttest. Jika hasil hitung lebih besar dari $\mathrm{t}_{\text {tabel }}$ maka treatment yang digunakan dengan layanan bimbingan kelompok cognitive behavior, efektif atau signifikan.

Dalam penelitian ini, peneliti mengajukan dua hipotesis yaitu hipotesis kerja $\left(\mathrm{H}_{\mathrm{a}}\right)$ dan hipotesa nihil $\left(\mathrm{H}_{0}\right)$. Kedua hipotesis tersebut sebagai berikut.
$\mathrm{H}_{\mathrm{a}}$ : pelaksanaan layanan bimbingan kelompok cognitive behavior efektif dalam mereduksi pola pikir negatif siswa SMK.

$\mathrm{H}_{0}$ : pelaksanaan layanan bimbingan kelompok cognitive behavior tidak efektif dalam mereduksi pola pikir negatif siswa SMK.

Ketentuan penerimaan dan penolakan hipotesis di atas adalah sebagai berikut.

Terima $\mathrm{H}_{0}=$ jika $\mathrm{t}_{\text {hitung }}<\mathrm{t}_{\text {tabel }}$; dengan kata lain $\mathrm{H}_{\mathrm{a}}$ ditolak.

Tolak $\mathrm{H}_{0}=$ jika $\mathrm{t}_{\text {hitung }}>\mathrm{t}_{\text {tabel }}$; dengan kata lain $\mathrm{H}_{\mathrm{a}}$ diterima.

\section{HASIL DAN PEMBAHASAN}

\section{Hasil}

Hasil pretest kuesioner pola pikir negatif terjaring 6 siswa yang dipilih sebagai sampel penelitian dan dapat dilihat pada tabel 4 .

Tabel 4

Hasil Pretest Siswa yang Mempunyai Pola Pikir Rendah

\begin{tabular}{ccc}
\hline No & Nama & Skor \\
\hline 1 & EI & 92 \\
2 & IP & 94 \\
3 & KO & 93 \\
4 & LK & 94 \\
5 & MR & 93 \\
6 & N & 93 \\
\hline
\end{tabular}

Setelah pemberian layanan bimbingan kelompok cognitive behavior kepada 6 siswa, selanjutnya diberikan posttest. Posttest ini dilakukan untuk membandingkan ada atau tidaknya perbedaan pola pikir siswa sebelum dan sesudah pemberian bimbingan kelompok cognitive behavior. Posttest dilakukan dengan memberi kuesioner pola pikir yang terdiri dari 38 item dan hasilnya dapat dijelaskan dalam tabel 5 .

Tabel 5

Hasil Posttest Tanggapan Responden terhadap KuesionerPola Pikir

\begin{tabular}{ccc}
\hline No & Nama & Skor Total \\
\hline 1 & EI & 132 \\
2 & IP & 113 \\
3 & KO & 121 \\
4 & LK & 140 \\
5 & MR & 125 \\
6 & N & 110 \\
\hline
\end{tabular}


Tabel 6

Perbedaan Hasil Pretest dan Posttest

\begin{tabular}{cccccc}
\hline Konseli & Pretest & Kriteria & Posttest & Kriteria & Kenaikan \\
\hline EI & 92 & Rendah & 132 & Tinggi & 40 \\
IP & 94 & Rendah & 113 & Sedang & 19 \\
KO & 93 & Rendah & 121 & Tinggi & 28 \\
LK & 94 & Rendah & 140 & Tinggi & 46 \\
MR & 93 & Rendah & 125 & Tinggi & 33 \\
N & 93 & Rendah & 110 & Sedang & 17 \\
\hline
\end{tabular}

Berdasarkan hasil skor hasil kuesioner pola pikir yang dicapai oleh 6 siswa tersebut mengalami perubahan dari yang semula mempunyai skor kategori rendah menjadi skor dalam kategori sedang dan tinggi. Uji T

Data pretest dan posttest 6 siswa kelas Multimedia 2 SMK dapat dilihat pada tabel 7.

Tabel 7

Descriptive Statistics

\begin{tabular}{lccccc}
\hline & N & Minimum & Maximum & Mean & $\begin{array}{c}\text { Std. } \\
\text { Deviation }\end{array}$ \\
\hline Pretest & 6 & 92 & 94 & 93.17 & 0.753 \\
Posttest & 6 & 110 & 110 & 123.50 & 11.362 \\
Valid N & 6 & & & & \\
\hline
\end{tabular}

Dari tabel 4 dan 6 dapat dikatakan bahwa data pretest yang diperoleh 6 siswa SMK berkaitan dengan pola pikir negatif dengan skor maksimal 94, skor minimal 92 dengan rata-rata 93.17 dan standar deviasi 0.753 , sedangkan data posttest yang diperoleh siswa SMK berkaitan dengan pola pikir negatif dengan skor maksimal 140, skor minimum adalah 110 dengan ratarata 123.50 dan standar deviasi 11.362.

Selanjutnya, dilakukan pengujian t-test (paired sampel test) dengan menggunakan progam SPSS 16.00 for Windows. Hasil pengujian tersebut dapat diamati pada tabel 8 .

Tabel 8

Ringkasan Hasil Uji Test terhadap Pretest dan Posttest Paired Sample Test

\begin{tabular}{|c|c|c|c|c|c|c|c|c|c|}
\hline \multirow[b]{3}{*}{$\begin{array}{l}\text { Pair } \\
1\end{array}$} & \multirow[b]{3}{*}{$\begin{array}{l}\text { Pretest- } \\
\text { Posttest }\end{array}$} & \multicolumn{5}{|c|}{ Paired Differences } & \multirow[b]{2}{*}{$\mathrm{t}$} & \multirow[b]{2}{*}{$\mathrm{df}$} & \multirow[b]{2}{*}{$\begin{array}{c}\text { Sig. } \\
\text { (2-tailed }\end{array}$} \\
\hline & & Mean & $\begin{array}{c}\text { Std. } \\
\text { Deviation }\end{array}$ & $\begin{array}{l}\text { Std. } \\
\text { Error } \\
\text { Mean }\end{array}$ & $\begin{array}{l}95 \% \mathrm{C} \\
\text { Interv } \\
\text { Diff }\end{array}$ & $\begin{array}{l}\text { ifidence } \\
\text { Of The } \\
\text { rence }\end{array}$ & & & \\
\hline & & 30.33333 & 11.43095 & 4.66667 & 42.32938 & 18.33728 & 6.500 & 5 & .001 \\
\hline
\end{tabular}

Dari tabel di atas diketahui bahwa harga $t_{\text {hitung }}$ adalah 6.500 dan angka probabilitas (Sig. (2-tailed) adalah 0.001 dengan $\mathrm{df}=5$. Selanjutnya harga tersebut dibandingkan dengan harga $t_{\text {tabel }}$ pada taraf signifikan $5 \%$ uji dua pihak dengan $\mathrm{df}=5$, sehingga diketahui harga $t_{\text {tabel }}$ adalah 6.500 atau $6.500>2.571$. Nilai probabilitas yang diperoleh adalah $0.001>0,005$ maka dapat dikatakan pola pikir siswa sebelum dan sesudah dilaksanakan bimbingan kelompok cognitive behavior terdapat perbedaan yang signifikan. Dengan kata lain, layanan bimbingan kelompok cognitive behavior efektif dalam mereduksi pola pikir negatif siswa SMK.

\section{Uji hipotesis penelitian}

Untuk mengetahui diterima atau tidaknya hipotesis yang diajukan dalam penelitian ini, dilakukan uji hipotesis. Hipotesis dalam penelitian ini adalah :

$\mathrm{H}_{0}$ : pelaksanaan layanan bimbingan kelompok cognitive behavior tidak efektif dalam mereduksi pola pikir negatif siswa SMK.

$\mathrm{H}_{\mathrm{a}}$ : pelaksanaan layanan bimbingan kelompok cognitive behavior efektif dalam mereduksi pola pikir negatif siswa SMK.

Adapun kriteria pengujian hipotesis adalah sebagai berikut.

Terima $\mathrm{H}_{0}$ : jika $\mathrm{t}_{\text {hitung }}<$ ttabel ; dengan kata lain $\mathrm{H}_{\mathrm{a}}$ ditolak Tolak $\mathrm{H}_{0}$ : jika $\mathrm{jhitung}>\mathrm{t}_{\text {tabel }}$; dengan kata lain $\mathrm{H}_{\mathrm{a}}$ diterima Dari perhitungan SPSS 16.00 for Windows didapat hasil harga $t_{\text {hitung }}$ adalah 6.500 dan angka probabilitas (Sig. (2-tailed) adalah 0.001 dengan $\mathrm{df}=5$, sedangkan harga $t_{\text {tabel }}$ pada taraf signifikan $5 \%$ uji dua pihak dengan df = 5 adalah 2.571. Dengan demikian, dalam penelitian ini dapat disimpulkan bahwa hipotesis kerja $\left(\mathrm{H}_{\mathrm{a}}\right)$ yang menyatakan, "Pelaksanaan layanan bimbingan kelompok cognitive behavior efektif dalam mereduksi pola pikir negatif siswa" diterima, sedangkan hipotesis nihil $\left(\mathrm{H}_{0}\right)$ yang menyatakan, "Pelaksanaan layanan bimbingan kelompok cognitive behavior tidak efektif dalam mereduksi pola pikir negatif siswa SMK" ditolak, karena $t_{\text {hitung }} 6.500>t_{\text {tabel }}$ 2.571 pada taraf signifikan $\alpha=0.05$.

\section{Pembahasan}

Penelitian ini menggunakan bimbingan kelompok cognitive behavior untuk mereduksi pola pikir negatif siswa SMK secara efektif. Dalam proses penelitian, peneliti berperan sebagai konselor yang menerapkan bimbingan kelompok cognitive behavior pada kelompok siswa yang memiliki pola pikir rendah. Penjaringan subjek dalam penelitian ini dilakukan dengan menggunakan inventori pola pikir, dari anggota yang teridentifikasi memiliki pola pikir rendah.

Berdasarkan alat ukur inventori pola pikir yang digunakan dalam penelitian ini terdapat 6 siswa dari anggota populasi yang teridentifikasi memiliki pola pikir rendah. Dalam bimbingan kelompok cognitive behavior, siswa diajak untuk berpikir lebih realistis dan mengarahkan perilakunya ke arah yang lebih baik lagi. Hal ini diterapkan dalam mereduksi pola pikir negatif siswa.

Menurut Sofian (dalam Elifky, 2013), pikiran 
negatif tidak datang begitu saja. Pikiran negatif merupakan akumulasi dari setiap hal yang seseorang lakukan atau terjadi di masa maupun pengaruh dari luar, seperti serbuan tayangan negatif dan pengaruh orang-orang terdekat, sedangkan menurut Elfiky (2013) pikiran negatif dipengaruhi oleh (a) riwayat masa lalu, (b) keinginan atau tujuan tidak jelas, (c) rutinitas negatif, (d) pengaruh internal, dan (e) pengaruh eksternal. Cognitive behavior didasarkan pada konsep mengubah pikiran dan perilaku negatif yang sangat mempengaruhi emosi. Melalui cognitive behavior, siswa terlibat aktivitas dan berpartisipasi dalam training untuk diri dengan cara membuat keputusan, penguatan diri, dan strategi lain yang mengacu pada self-regulation (Matson \& Ollendick, 1988).

Oemarjoedi (dalam Muqodas, 2011) menyatakan bahwa cognitive behavior mengajak konseli untuk menentang pikiran dan emosi yang salah dengan menampilkan bukti-bukti yang bertentangan dengan keyakinan tentang masalah yang dihadapi. Konselor diharapkan mampu menolong konseli untuk mencari keyakinan yang sifatnya dogmatis dalam diri konseli dan secara kuat mencoba menguranginya.

Perubahan dari pola pikir otomatis siswa SMK dapat dilihat dari kriteria perbedaan skor pada pretest dan posttest. Di sini terdapat 6 siswa yang mempunyai pola pikir negatif atau pola pikir rendah yang dijadikan sampel. Enam siswa ini didapat dari skor hasil pretest dengan menggunakan kuesioner pola pikir.

Dilihat dari analisis semua subjek penelitian mengalami peningkatan skor pada posttest pola pikir. Perubahan begitu signifikan, hal itu terlihat setelah diberikan treatment bimbingan kelompok cognitive behavior.

Penerapan bimbingan kelompok cognitive behavior pada siswa yang memiliki pola pikir rendah atau pola pikir negatif untuk pertemuan pertama, pertama-tama konselor dan konseli kenalan satu sama lain untuk proses pengakraban, konseli pertama bernama EI. Berdasarkan hasil skor pretest, EI mempunyai pola pikir rendah atau negatif. Hal yang membuat El mempunyai pola pikir negatif dipengaruhi oleh masa lalunya. EI mengatakan bahwa tidak bisa move on dari masa lalunya dimana EI selalu terbayang saat kecil sering dibohongi oleh temantemannya, dan akhirnya terbawa hingga sekarang. Hal tersebut mengakibatkan EI tidak mempercayai teman-temannya. Kemudian yang dilakukan konselor adalah memberikan treatment relaksasi, dengan membayangkan bahwa hal-hal yang sudah lalu dihilangkan atau dihentikan dan diganti dengan membayangkan hal-hal yang lebih positif. Setelah melalui proses relaksasi, EI mengalami ketenangan. Kemudian pada pertemuan selanjutnya konselor memberi cara bagaimana menghadapi pola pikir negatif dan penanganannya, sehingga konseli EI tahu cara menghentikan pikiran negatif saat berada di mana saja dan kapan saja.

LK adalah siswa yang menjadi sampel berikutnya dan diberi treatment oleh konselor dengan bimbingan kelompok cognitive behavior. LK merupakan salah satu siswa yang mempunyai pola pikir negatif yang disebabkan kurangnya kasih sayang dari orang tua sehingga harus diberikan treatment. Ketika konselor menjelaskan hal-hal apa saja yang menyebabkan pola pikir negatif, dan bertanya mengapa hal tersebut terjadi, LK mengatakan bahwa orang tuanya selalu pilih kasih dalam hal kasih sayang kepada dirinya dengan adiknya. LK beranggapan bahwa adiknya selalu diistimewakan, sedangkan dirinya tidak pernah diistimewakan oleh orang tuanya sebagaimana orang tuanya mengistimewakan adiknya. Kemudian, konselor memberi kesempatan anggota lain untuk memberi saran kepada LK cara membantu LK keluar dari perangkap pola pikir negatif tersebut. Setelah anggota memberi saran, LK mulai sedikit tahu dan mengerti mengapa orang tua membagi porsi yang berbeda terhadap dirinya dan adiknya. Kemudian hal yang dilakukan konselor adalah mengidentifikasi hal-hal apa saja yang menyebabkan konseli berpikiran negatif pada keluarganya. Konselor memberikan latihan untuk mengubah perilaku konseli dengan kontruksi pikiran otomatis. Hal ini dilakukan agar konseli mengerti dan dapat berpikir lebih rasional tentang apa yang dipikirkannya selama ini. Langkah selanjutnya, konselor memberi posttest setelah melakukan treatment tersebut. Hasil dari posttest LK telah terlihat kenaikannya dari pola pikir rendah dengan skor 94 menjadi 140, merupakan kenaikan tertinggi dari anggota lainnya.

$\mathrm{KO}$ adalah siswa yang juga perlu diberikan treatment. Dari skor kuesioner yang telah dibagikan konselor, KO mempunyai skor pola pikir rendah sebesar 93. Faktor yang menyebabkan KO memiliki pola pikir negatif adalah lingkungannya. KO mengatakan bahwa lingkungan sekitarnya tidak baik, sehingga enggan keluar rumah dan memilih di rumah dan jarang bergaul dengan teman dan lingkungan sekitarnya. Kemudian konselor mengajak konseli untuk latihan kognitif dengan menggunakan imajinasi untuk membayangkan secara detail hal-hal positif apa saja yang dapat dilakukan di lingkungan sekitarnya. Setelah diberi treatment bimbingan 
kelompok cognitive behavior, KO mulai sedikit terbuka dan ingin mencoba untuk lebih bergaul dengan temanteman di lingkungan sekitarnya. Selain itu, KO juga menjadi tahu cara memilih teman yang tepat untuk dirinya. Bimbingan kelompok cognitive behavior dapat meningkatkan pola pikir $\mathrm{KO}$, dilihat dari hasil posttest yang mengalami kenaikan dari skornya rendah yakni 93 menjadi 121. Pola pikir yang dulu rendah sekarang menjadi sedang.

IP adalah konseli selanjutnya yang mengikuti kegiatan bimbingan kelompok cognitive behavior. Dari hasil pretest, IP mempunyai pola pikir rendah sehingga dapat dijadikan sampel penelitian. Konselor mengetahui IP mempunyai pola pikir negatif disebabkan oleh faktor keluarga. Hal ini dilihat dari indikator pretest yang sudah diberikan. Konselor mengidentifikasi alasan IP beranggapan tidak baik kepada keluarganya dan hasilnya hampir sama dengan LK, bahwa IP menilai orang tuanya seperti tidak menganggapnya dan kurang memperhatikannya. Hal yang dilakukan konselor selanjutnya adalah menemukan pikiran negatif IP, kemudian dilakukan relaksasi dengan meminta IP berbaring dan menutup mata untuk melepaskan semua pikiran negatifnya dan membayangkan hal-hal yang bersifat positif tentang apa saja kebaikan yang sudah dilakukan orang tuanya kepada IP. Kemudian konselor melanjutkan tahaptahap bimbingan kelompok cognitive behavior dengan meminta anggota lain memberikan pendapat tentang apa yang menjadi masalah IP. Setelah diberikan treatment, IP menyadari bahwa banyak hal yang telah dilakukan orang tuanya sehingga membuat dia bahagia. Akhirnya pikiran otomatis IP meningkat, terbukti dari skor posttest yang naik dari yang sebelumnya mempunyai skor rendah 94 meningkat menjadi 113, pola pikirnya pun lebih baik dari pada sebelumnya.

MR merupakan siswa yang tergolong mempunyai pola pikir rendah. Sama halnya seperti IP, MR beranggapan bahwa orang tuanya juga tidak perhatian pada dirinya. Atas dasar tersebut konselor memberikan treatment yang sama dengan semua konseli, pertama memberi penjelasan halhal apa saja yang mempengaruhi pola pikir negatif, kemudian diberi relaksasi dan mengajak berpikir yang lebih realistis. Selanjutnya, memberi gambaran cara mengubah pola pikir dan perilaku sehingga MR tahu dan mengerti apa yang menyebabkan memiliki pola pikir negatif serta bagaimana cara mengatasi masalahnya. Setelah merasa nyaman dengan konselor, konselor pun memberikan posttest untuk menentukan hasil dari perubahan pola pikir MR. Dari hasil yang didapatkan baik dari pretest ataupun posttest, terlihat adanya peningkatan pola pikir, dari rendahnya skor pola pikir siswa yakni 93 meningkat menjadi 125 .

Konseli terakhir adalah N. Dilihat dari skor pretest, $\mathrm{N}$ mempunyai pola pikir negatif yang disebabkan adanya anggapan sering tidak mampu melakukan sesuatu dalam segala hal, dengan kata lain, $\mathrm{N}$ memiliki sifat pesimis. Di sinilah keefektifan bimbingan kelompok cognitive behavior diuji. Konselor berusaha meyakinkan bahwa anggapan $\mathrm{N}$ salah dan konselor memberi keterampilan memecahkan masalah bagi konseli. N pada awalnya ragu-ragu dalam menghadapi sesuatu, tetapi setelah diberi tahapan keterampilan memecahkan masalah, N menjadi anak yang lebih percaya diri dan optimis dalam menghadapi sesuatu. Setelah pemberian layanan bimbingan kelompok cognitive behavior selesai, langkah selanjutnya konselor memberikan soal posttest seperti yang lainnya. Hasil dari posttest, $\mathrm{N}$ telah terlihat kenaikannya dari pola pikir yang rendah dengan skor 93, menjadi sedang dengan skor 110.

Berdasarkan penjabaran di atas dapat disimpulkan bahwa pemicu pola pikir negatif adalah dari individu sendiri yang menganggap segala sesuatu dari sisi negatif dari pada sisi positifnya. Jika terlalu banyak mempunyai pola pikir negatif, alangkah lebih baik untuk menguranginya dan jika mempunyai pola pikir negatif sedikit, alangkah lebih baik untuk dapat segera dihilangkan. Oleh karena itu, bimbingan kelompok cognitive behavior merupakan sebuah layanan yang efektif dalam mereduksi pola pikir negatif siswa.

\section{PENUTUP}

\section{Kesimpulan}

Berdasarkan hasil penelitian, maka dapat disimpulkan bahwa bimbingan kelompok cognitive behavior efektif dalam mereduksi pola pikir negatif siswa. Hal ini diketahui dari perhitungan SPSS 16.00 for Windows, diketahui $t_{\text {hitung }}$ adalah sebesar 6.500 dan angka probabilitas (Sig. (2-tailed) adalah 0.001 dengan $\mathrm{df}=5$. Selanjutnya, harga tersebut dibandingkan dengan harga $t_{\text {tabel }}(2.571)$ atau $6.500>2.571$ dan nilai probabilitas yang diperoleh adalah 0.001 lebih kecil dari 0.005. Dengan demikian, dalam penelitian ini dapat disimpulkan bahwa pelaksanaan layanan bimbingan kelompok cognitive behavior efektif dalam mereduksi pola pikir negatif siswa SMK.

\section{Saran}

Berdasarkan hasil penelitian dan kesimpulan, maka saran yang dikemukakan sebagai berikut (1) bagi 
guru BK di SMK diharapkan menerapkan bimbingan kelompok cognitive behavior untuk mereduksi pola pikir negatif siswa, karena hasil penelitian ini terbukti bahwa bimbingan kelompok cognitive behavior efektif dalam mereduksi pola pikir negatif siswa SMK; (2) bagi peneliti selanjutnya, (a) diharapkan bagi peneliti selanjutnya untuk meneliti dengan menggunakan data yang lebih lengkap supaya hasilnya lebih optimal, (b) penelitian bisa menggunakan desain penelitian lain selain One Grup Pretest and Posttest Design misalnya desain Time Series dan single subject design, dan (c) hasil penelitian ini juga dapat dijadikan rujukan untuk peneliti selanjutnya yang berhubungan dengan bimbingan kelompok cognitive behavior.

\section{DAFTAR PUSTAKA}

Arikunto, S. (2010). Penelitian suatu pendekatan praktik edisi revisi. Jakarta: PT. Rineka Cipta.

Depdiknas. (2012). Dokumen kurikulum 2013. Jakarta: Kemendikbud.

Dewi, S., Tobing, D. H., \& Hizkia, D. (2014). Kebermaknaan hidup pada anak pidana di Bali. Jurnal Psikologi Udayana, 1(2), 322-334.

Elfiky, I. (2013). Terapi berpikir positif. Jakarta: Penerbit Zaman.

Habsy, B. A. (2017a). Model konseling kelompok cognitive behavior untuk meningkatkan self esteem siswa SMK. Perspektif Ilmu Pendidikan, 31(1), 21-35. doi: https:/ / doi.org/10.21009/PIP.311.4

Habsy, B. A. (2017b). Filosofi ilmu bimbingan dan konseling Indonesia. Jurnal Pendidikan (Teori dan Praktik), 2(1), 1-11. doi: http://dx.doi. org/10.26740/jp.v2n1.p1-11

Habsy, B. A. (2018a). Konseling rasional emotif perilaku: sebuah tinjauan filosofis. Indonesian Journal of Educational Counseling, 2(1), 13-30. doi: https:/ / doi.org/10.30653/001.201821.25

Habsy, B. A. (2018b). Model bimbingan kelompok PPPM untuk mengembangkan pikiran rasional korban bullying siswa SMK etnis Jawa. Jurnal Pendidikan (Teori dan Praktik), 2(2), 91-99. doi: http://dx.doi.org/10.26740/jp.v2n2.p91-99
Hurlock, E. B. (1966). Adolescent development (3rd ed.). New York, NY, US: McGraw-Hill.

Mardhika, R. (2016). Hubungan pola pikir negatif dan kecemasan terhadap cara berbicara di depan umum mahasiswa program studi pendidikan kepelatihan olahraga. Jurnal Buana Pendidikan, 12(22), 88-98. http://jurnal.unipasby.ac.id/ index.php/jurnal_buana_pendidikan/article/ view $/ 620$

Matson, J. L., \& Ollendick, T. H. (1988). Enhancing children's social skills. Oxpord: Pergamon Press.

Muqodas, I. (2011). Cognitive-behaviour theraphy: Solusi pendekatan praktek konseling di Indonesia. Diakses dari http://idatmuqodas.blogspot. com/2012/02/cognitive-behaviortherapy-solusi.html

Rini, J. F. (2002). Memupuk rasa percaya diri. Jakarta: Team e-Psikologi.

Rusydi, A. (2012). Husn Al-Zhann: Konsep berpikir positif dalam perspektif psikologi islam dan manfaatnya bagi kesehatan mental. Jurnal Proyeksi, 7(1), 1-31. doi: http://dx.doi. org/10.30659/p.7.1.1-31

Santrock, J. W. (2003). Perkembangan remaja. Jakarta: Erlangga.

Sary, Y. N. E. (2017). Perkembangan kognitif dan emosi psikologi masa remaja awal. J-PENGMAS (Jurnal Pengabdian kepada Masyarakat), 1(1), 6-12. http://ojshafshawaty.ac.id/index.php/jpengmas/article/view/1

Siregar, E. Y. (2013). Penerapan cognitive behavior therapy (cbt) terhadap pengurangan durasi bermain games pada individu yang mengalami games addiction. Jurnal Psikologi, 9(1), 17-24. doi: http:/ / dx.doi.org/10.24014/jp.v9i1.136

Sugiyono. (2013). Metode penelitian pendidikan pendekatan kuantitatif, kualitatif, dan RED. Bandung: Alfabeta.

Wati, S. (2017). Efektivitas pendekatan konseling kognitif perilaku dalam mengatasi dampak negatif alat komunikasi (smartphone) pada peserta didik kelas XI SMK PGRI 4 Bandar Lampung tahun 2015-2016. Tesis. Lampung: IAIN Raden Intan Lampung. 